\title{
CHESS AS A SOCIAL VALUE
}

\section{Abstract}

In this changing world, the process of preparing the child for life is getting more and more complicated. This article shows the importance of the ability to learn and the role of chess as a school subject. This article aims to study the benefits of chess in developing social values such as honesty, cooperation, discipline, foresight, and purposefulness. The research was carried out in 2 directions. The first phase of the study was to determine the attitude of stakeholders towards chess as a school subject. The second direction was to study the abilities, skills and values developed with the help of chess- the dates of made survey point the role of chess in developing schoolchildren's thinking. After the analyses, it was apparent that chess promotes the creation and development of children's linguistic-logical and algorithmic thinking, the ability to foresee, influencing the situation, assessing the importance of education by developed imagination and creativity. The involvement of chess in education was an essential step. It is of great importance in the development of our country.

Keywords: chess, primary school children, attitude, social value, Rokeach's value survey

\section{Introduction}

In this changing world, the process of preparing the child for life is getting more and more complicated. In this situation, the only stable value is the ability to learn. And this ability is promoted by the general education of the Republic of Armenia. In the conditions of current socio-cultural transformation, one needs to be provided with ongoing educational changes. So, it was expected that the involvement of a new subject in education had brought contradictory ideas.

The involvement of chess in education was an essential step. It is of great importance in the development of our country.

Why is chess necessary? It is to make sure that chess is beneficial not only for mind and cognition development (Gershunski, 1991, p. 336) and for teaching children significant features for future life. 
Being interested in such kind of problems, stakeholders included in pedagogical processes the initiatives of Chess Academy of Armenia - set up research on the social value of chess as a school subject.

The research was carried out in 2 directions. The first phase of the research was to find out the attitude of stakeholders towards chess as a school subject. The second direction was to study the abilities, skills and values developed with the help of chess.

The elementary school children were chosen to take part in the first phase of the research to determine whether they realise the importance of chess in their cognitive processes. The research was done in May 2014. The standardised model of the interview was used. The model contained multiple-choice questions. The interviewed children were 2-4 grade ones, and the total number was 264 . They were from different communities of Yerevan, one big and one small school from each community.

In the second phase, a socio-psychological investigation was done to discover and assess the means-values developed by the influence of a chess subject, taking Rokeach's methodology of value theory as a base (Rokeach, 1973, p. 276).

As for the interviewed children's age, the interview was organised using tales and stories that contained important values known by children.

The children were provided with 10 cards with an illustrated story or a tale on each. They were to choose one of them according to importance and priority for them. From the choice of the story, the values important for the children were discovered.

The main objective of the research was to find out the children's preferences of school subjects. So, $43 \%$ of the respondents put chess in the top 3 favourite subjects. For $11 \%$, chess is in the first place, and for $5 \%$, it is in the second place, and for $27 \%$, it is in the third place (Diagram 1).

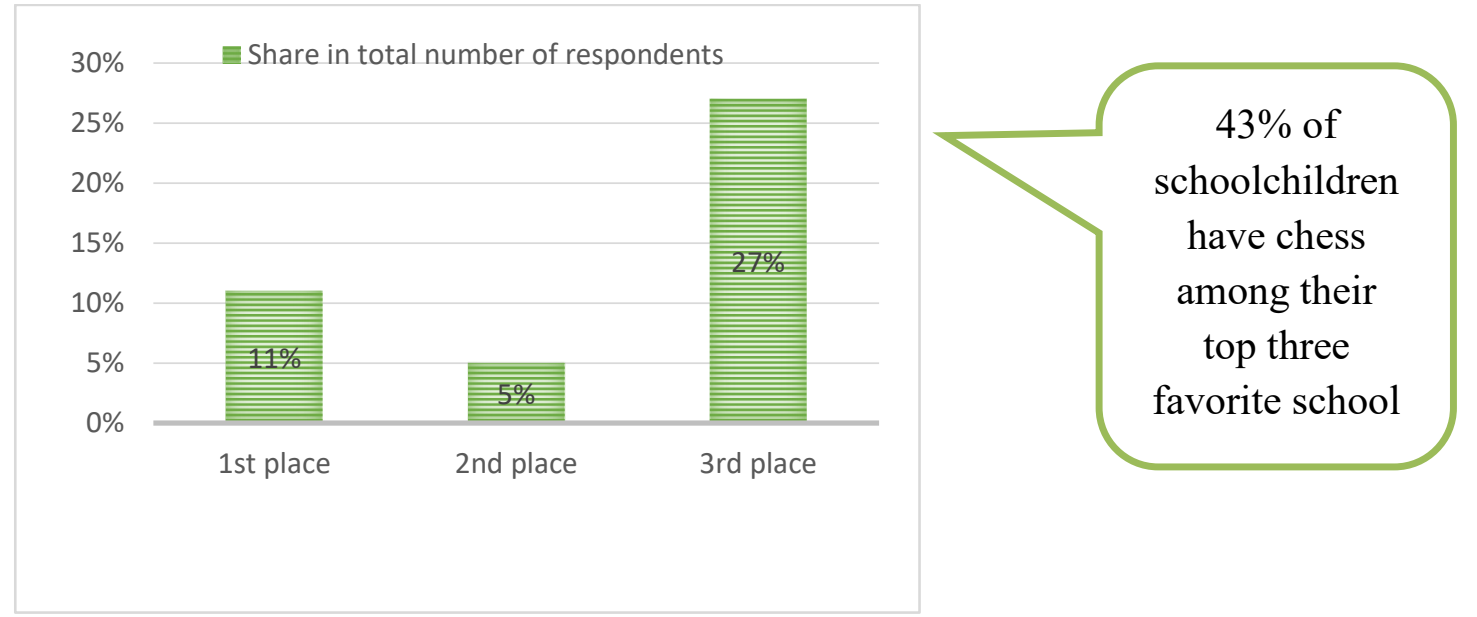

Diagram 1

The fact that children like chess was detectable through the other objective's. 
The majority of the responders ( $88 \%$ ) liked chess as a subject; boys $85 \%$ and $15 \%$, boys $92 \%$ and $8 \%$. Love is essential to develop a value, skill (diagrams 2,3 ).

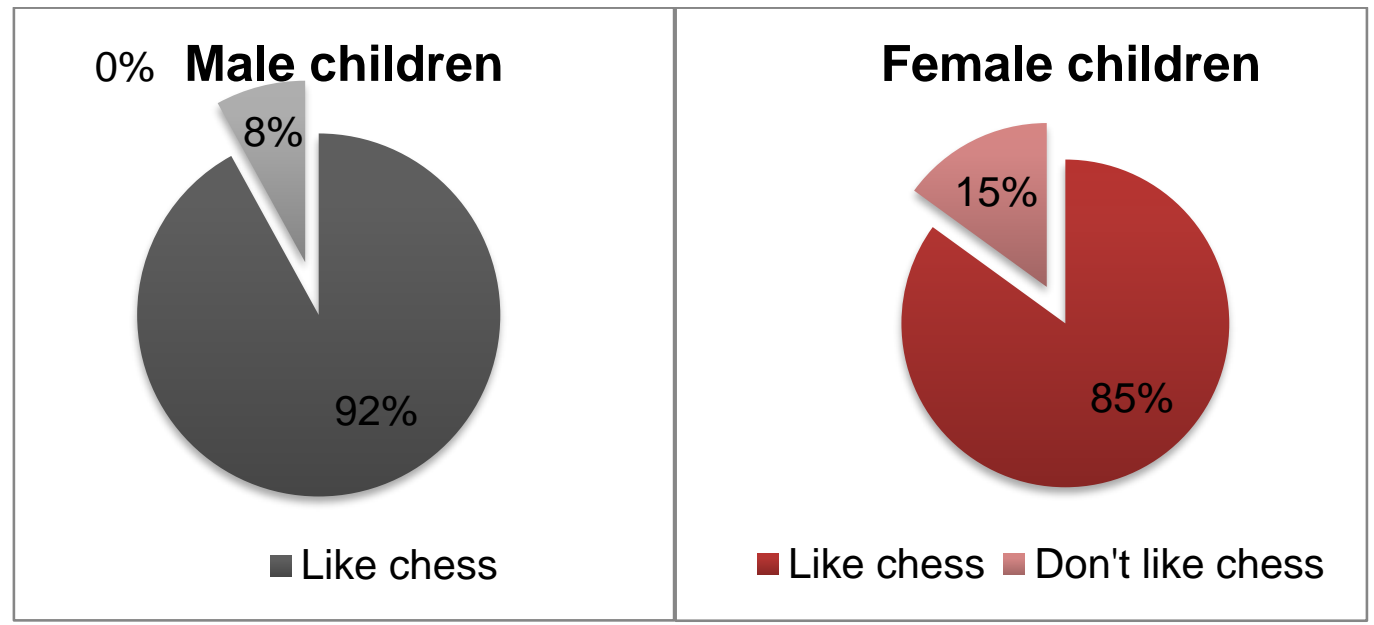

\section{Diagram 2 diagram 3}

Having the hypothesis that chess can develop the required values, features for $21^{\text {st }}$ century children, content analyses were done on the subject standard outcomes, the teachers' manual of chess subject.

After the analyses, it was apparent that chess promotes the creation and development of children's linguistic-logical and algorithmic thinking, foreseeing, influencing the situation, and assessing the importance of education by developing imagination and creativity. Besides, each chess problem is aimed at creating and developing a specific quality, i. e. moderation, active memory, cooperation, etc. (diagram 4). Chess game develops during struggle and struggle develops thinking, teaches to assess, analyse, combine, make good decisions, etc. For example, the first lesson dedicated to the introduction of King's moves aims to understand the final goal of the game. Current problems usually make individuals give up the final goal, and chess helps always to remember individual targets, priorities. 


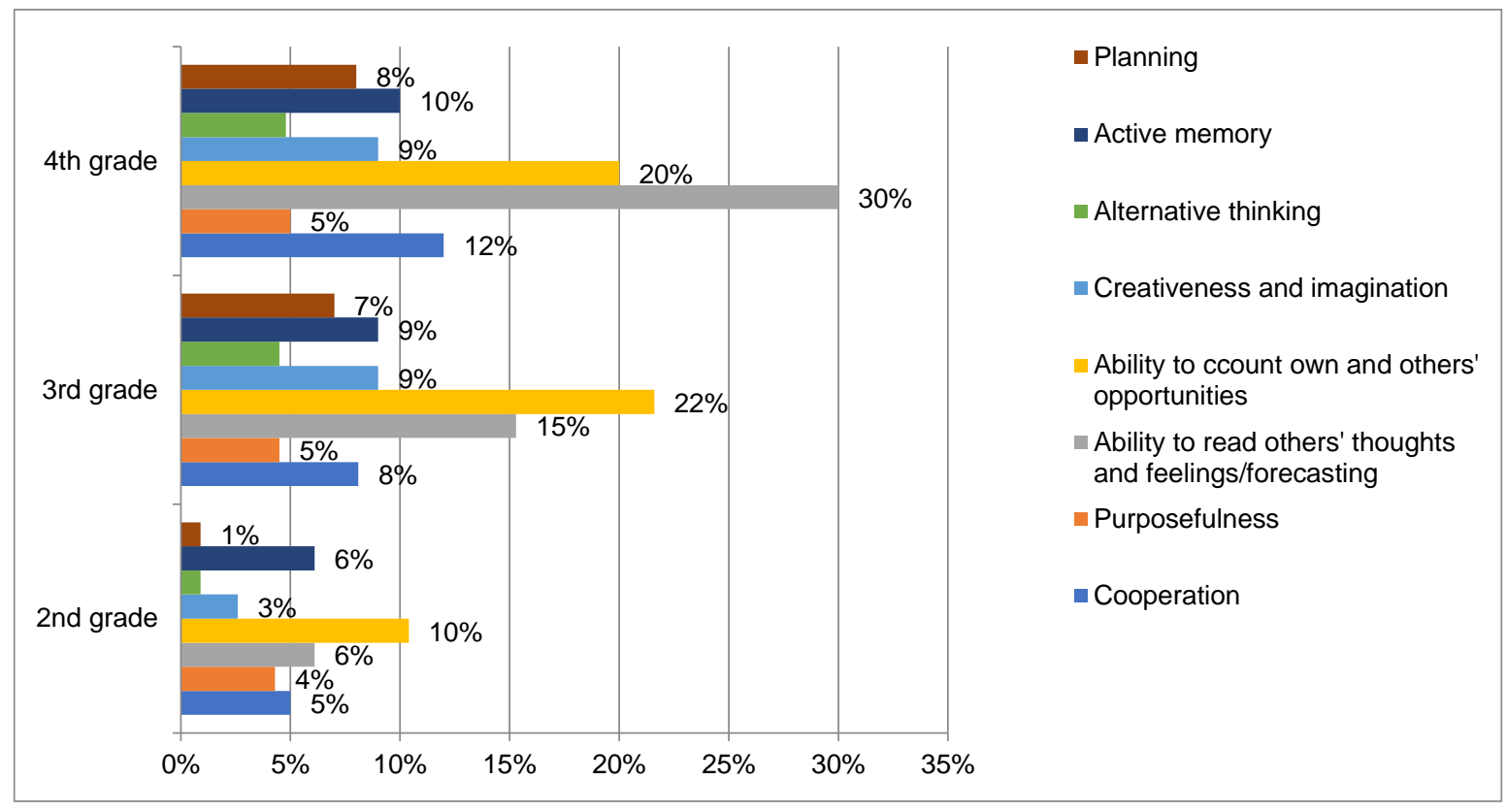

Diagram 4

Let's consider chess problems and diagrams in order to give the children a chance to make alternative solutions. From this point, chess helps to create and develop divergent thinking (Gilford, 1965, p. 45). For instance, Unit 16 in the $3^{\text {rd }}$ grade is a lesson just about thinking and protection and aims to set goals that is one of the essential needs of the current society. It teaches children to react to the situation adequately.

Therefore, we can state that chess develops particular abilities which contribute to the classification of values. In this case, chess is considered to be an instrumental value used for self-perception aimed at being accepted by the family and society.

Chess also makes it possible to create and develop values such as understanding the necessity of working with others, that is to say, cooperation, responsibility, honesty, discipline, farsightedness, and understanding possibilities of different problem solutions.

In order to find out whether these abilities have a specific influence on the classification of values of primary school children, research has been carried out participating 60 schoolchildren from second /20 children /, third /20 children/, fourth /20 children/ grades. They were divided into four subgroups:

Children who have high academic progress in Mathematics, the Armenian Language, and Chess;

Children who have high academic progress in Mathematics and the Armenian language but have low academic progress in Chess;

Children who have low academic progress in Mathematics, the Armenian language, and Chess; 
Children who have low academic progress in Mathematics, the Armenian Language, but have high academic progress in Chess.

The basis for the latter classification was the fact that academic progress reflects the amount of influence of the understanding of the subject, therefore, behaviour, thinking, etc.

While doing the research, a fact took our attention, that was in each subgroup, a pattern was noticeable; children who solved chess problems easily have a more qualitative cooperation value. After all, we can state that chess subject, mainly particular topics /Unit 21,37 in the $3^{\text {rd }}$ grade/ really helps to create and develop cooperation interaction between children. Meanwhile, children with low academic progress in chess have little cooperation in the value system.

In subgroups of children with high academic progress in chess, a high level of attention and concentration is noticeable. Values such as honesty, cooperation, discipline, and purposefulness are the first place for the children (pic. 1).

\begin{tabular}{|c|c|c|}
\hline 10 Insight & 10 Insight & 10 Insight \\
\hline 9 Justice & 9 & 9 Contrivance \\
\hline & Tolerance & \\
\hline $\begin{array}{l}8 \\
\text { Purposefu }\end{array}$ & $\begin{array}{l}8 \\
\text { Contrivan }\end{array}$ & 8 Tolerance \\
\hline $\begin{array}{l}\text { Iness } \\
7\end{array}$ & $\begin{array}{l}\text { ce } \\
7\end{array}$ & 7 \\
\hline $\begin{array}{l}\text { Contrivan } \\
\text { ce }\end{array}$ & $\begin{array}{l}\text { Responsib } \\
\text { ility }\end{array}$ & responsibility \\
\hline 6 & $\begin{array}{l}6 \\
\text { Purposefu }\end{array}$ & 6 justice \\
\hline $\begin{array}{l}\text { on } \\
5\end{array}$ & $\begin{array}{l}\text { Iness } \\
5 \text { Justice }\end{array}$ & 5 \\
\hline Foresight & & $\begin{array}{l}\text { Purposefuines } \\
\text { s }\end{array}$ \\
\hline 4 Honesty & 4 & 4 cooperation \\
\hline $\begin{array}{l}\text { good at math and mother tongue } \\
\text {,poor at chess }\end{array}$ & $\begin{array}{c}\text { Foresight } \\
\text { good at chess, poor at math } \\
\text { and mother tongue }\end{array}$ & $\begin{array}{l}\text { good at chess, } \\
\text { math and } \\
\text { mother tongue }\end{array}$ \\
\hline
\end{tabular}

Pic 1

We can assume from the following that chess subject like Chess game has a royal influence on the development and of royal qualities, the revival of moral values. Moreover, in these subgroups, purposefulness dominates compared with those in other subgroups/purposefulness is in places 5-6, while in the other subgroup, it is in place $8 /$. It promotes the development of willpower to win. 
From the table, it is obvious one more thing, in the subgroups with high academic progress, foresight is primary, which gives a chance to ally the intolerance in existential situations.

To sum up, for children with high academic progress, the most important values are honesty, cooperation, discipline, foresight, purposefulness. It comes to prove that chess can be a feature developing subject with the help of game activities.

On the other hand, in the subgroups of children with low academic progress, we see uncertainty, absence of orientation of values, which is the result of not regulated thinking, behaviour. Unfortunately, in current reality, these children constitute a considerable number.

For this reason, it is suggested, as probation, discover by monitoring schoolchildren's educational difficulties, and by focusing on the chess progress development fix the possible change also in other subject difficulties.

And also, a secondary school support centre is suggested to be created. Its initial objectives will be cooperation interaction organization for teaching chess successfully, retraining for pedagogical methodology, development of the parent-teacher-child trilateral model. The latter will help to discover problems in secondary education and to react adequately. It's worth paying attention to the fact that the quality of finesse is in the last place in the value system of interviewed children. It should be mentioned that these features are reflections of flexible thinking and logics. It proves that chess can cause quality change by way of regular and consistent learning. Thus, it is preferable to include chess in the first two years of schooling as it develops stable bases for developing alternative thinking.

\section{References}

Gershunski, B. S. (1991). Shakhmati-shkole (Chess to school, in Russian) Moscow: Pedagogika.

Gilford, J. (1965). Tri storoni intelekta, Psikhologiya mishleniya (Three sides of intelligence, Psychology of thinking, in Russian) Moscow.

Rokeach, M. (1973). Priroda chelovecheskikh cennostey (The Nature of Human Values, in Russian) New York. 